\title{
Aspek Hukum Peraktik Kedokteran Melakukan Tindakan Medis Yang Bukan Kewenangan Kompetensi Profesinya
}

\author{
Ricky \\ Fakultas Hukum Universitas Islam Indonesia Yogyakarta Indonesia \\ Jln. Cik Di Tiro, Daerah Istimewa Yogyakarta Indonesia \\ rikiriau15@gmail.com
}

\begin{abstract}
Abctract
This research was conducted to determine the limits of doctors in carrying out medical actions that are beyond the authority of their professional competence. This study is based on data that there are still doctors who perform medical actions beond their authority. This is normative legal research that is supported by empirical data by collecting legal materials and interviews. This paper concludes that the doctor's authority in performing medical practice is required to have a Registration Certificate (STR) and License to Practice (SIP), as regulated in Articles 29 and 36 of Law Number 29 of 2004 on Medical Practice. A doctor is not allowed to take medical action beyond their competence since they possess no certificate of competence that recognizes their study during the educational process as regulated in Article 69 paragraph (1) of Law Number 36 Year 2009 on Health, if they are unable to carry out an examination and treatment then they can carry out the referral process to doctors who have expertise as regulated in Article 27 letter (b) of Law Number 29 of 2004 on Medical Practice.
\end{abstract}

Key Words: Doctors' authority; doctors' competence; medical treatment

\begin{abstract}
Abstrak
Tulisan ini dilakukan untuk mengetahui batasan dokter dalam melakukan tindakan medis yang bukan kewenangan kompetensi profesinya. Tulisan ini didasarkan pada data masih ada dokter yang melakukan tindakan medis di luar kewenangannya. Sebagai penelitian hukum normatif yang didukung oleh data empiris dengan cara pengumpulan bahan hukum peraturan perundang-undangan dan wawancara. Tulisan ini menyimpulkan bahwa kewenangan dokter dalam melakukan peraktik kedokteran wajib memiliki Surat Tanda Registrasi (STR) dan Surat Izin Peraktik (SIP), sebagaimana diatur di dalam Pasal 29 dan 36 Undang-Undang Nomor 29 Tahun 2004 tentang Peraktik Kedokteran. dokter tidak diperbolehkan mengambil tindakan medis yang bukan kompetensinya selama tidak memilki sertifikat kompetensi atas pengakuan apa yang diperolehnya pada masa proses pendidikan sebagaimana diatur di dalam Pasal 69 ayat (1) Undang-Undang Nomor 36 Tahun 2009 tentang Kesehatan, apabila tidak mampu melakukan pemeriksaan dan pengobatan maka melakukan proses rujukan kepada dokter yang mempunyai keahlian dan lebih baik yang diatur di dalam Pasal 27 huruf (b) Undang-Undang Nomor 29 Tahun 2004 tentang Peraktik Kedokteran.
\end{abstract}

Kata-kata Kunci: Kewenangan dokter; kompetensi dokter; tindakan medis 


\section{Pendahuluan}

Pasal $28 \mathrm{H}$ ayat (1) Undang-Undang Dasar Negara Republik Indonesia Tahun 1945 (UUD NRI 1945) menyatakan, setiap orang berhak hidup sejahtera lahir dan batin bertempat tinggal dan mendapatkan lingkungan hidup yang baik dan sehat serta berhak memperoleh pelayanan kesehatan. ${ }^{1}$ Sejatinya setiap orang berhak atas mendapatkan pelayanan kesehatan yang bermutu, berkualitas dan aman adalah hak asasi bagi setiap individu. ${ }^{2}$

Kesehatan merupakan indikator untuk mengukur keberhasilan pembangunan manusia, dan tentunya tanpa kesehatan manusia tidak akan produktif untuk hidup layak secara ekonomis dan menjalani pendidikan yang baik pula, kesehatan merupakan hak asasi manusia dan salah satu unsur kesejahteraan yang harus diwujudkan sesuai dengan impian bangsa indonesia sebagaimana yang dimaksud di dalam Pancasila dan Undang-Undang Dasar $1945 .^{3}$

Setiap kegiatan dan upaya untuk meningkatkan derajat kesehatan masyarakat yang setinggi-tingginya dilaksanakan berdasarkan perinsip nondiskriminatif, parsitipatif, perlindungan dan berkelanjutan yang sangat fundamental bagi pembentukan sumberdaya manusia Indonesia, peningkatan ketahanan dan daya saing bangsa serta pembangunan nasional. ${ }^{4}$

Pembangunan nasional harus dilandasi dengan wawasan kesehatan yang artinya pembangunan nasional itu sendiri harus memperhatikan kesehatan masyarakat. Apabila terjadi suatu hal yang menyebabkan gangguan kesehatan pada masyarakat Indonesia tentunya akan menimbulkan kerugian ekonomi yang besar bagi negara, tapi di sisi lain setiap keberhasilan upaya peningkatan derajat kesehatan masyarakat akan meningkatkan investasi bagi pembangunan negara. Dengan demikian, semua pihak baik pemerintah maupun masyarakat bertanggung jawab dalam memperhatikan kesehatan masyarakat. 5

Pelayanan kesehatan yang bermutu merupakan suatu kebutuhan dasar yang diperlukan setiap anggota masyarakat, pelayanan kesehatan yang dilakukan profesi kedokteran haruslah sesuai dengan standar profesi, standar prosedur

${ }^{1}$ Pasal 28 H ayat (1) Undang-Undang Dasar Negara Republik Indonesia Tahun 1945.

2 Machli Riyadi, Teori Iknemook dalam Mediasi Malapraktik. Medik, Jakarta, Prenamedia, 2018, hlm. 1.

${ }^{3}$ Sri Siswati, Etika dan Hukum Kesehatan dalam Perspektif Undang-Undang Kesehatan, Jakarta, Rajawali Press. 2015, hlm. 3.

4 Fherial Sri Isriyawati, Tanggungjawab Negara Dalam Pemberian Hak Atas Kesehatan Masyarakat Berdasarkan Undang-Undang Dasar Negara Republik Indonesia Tahun 1945, Jurnal Ilmu Hukum Legal Opinion, Edisi 2. Vol. 3 Tahun 2015, hlm. 2.

5 Bunga Agustina, Kewenangan Pemerintah Dalam Perlindungan Hukum Pelayanan Kesehatan Tradisional Ditinjau Dari Undang-Undang Republik Indonesia No. 36 Tahun 2009 Tentang Kesehatan, Jurnal Wawasan Hukum, Vol. 32. No. 1 Februari 2015. 
operasional dan kebutuhan medis pasien dalam melaksanakan peraktik kedokteran, karena profesi dokter adalah seseorang yang memiliki keilmuan dan keterampilan untuk menyembuhkan orang-orang yang sakit. Dokter sebagai orang yang memiliki ilmu dibidang kedokteran memiliki kewenangan dan izin sebagaimana mestinya untuk melaksanakan pelayanan kesehatan dan memeriksa serta mengobati pasien yang datang padanya menurut ketentuan di bidang hukum pelayanan kesehatan. ${ }^{6}$

Dalam peraktik pelayanan kesehatan tampak bahwa hubungan dokter dan pasien merupakan hubungan yang tidak seimbang karena dokter mempunyai kedudukan yang lebih tinggi dan mempunyai pengetahuan dibidang kedokteran, sementara itu pasien berada dalam ketidakberdayaan dan tidak mempunyai pengetahuan dibidang ilmu kedokteran. Dengan demikian dalam hal ini harus diusahakan adanya keseimbangan. ${ }^{7}$

Hubungan hukum antara dokter dengan pasien ini berawal dari pola hubungan vertical paternalistik, hubungan hukum timbul apabila pasien menghubungi dokter karena ia merasa ada sesuatu yang dirasakannya membahayakan kesehatannya. Dan dalam hal ini dokterlah yang dianggap mampu menolongnya dan memberikan bantuan pertolongannya. ${ }^{8}$ Pola hubungan ini sudah tidak sesuai lagi dengan perkembangan zaman lebih dari setengah abad yang lalu para ahli hukum dan dokter mulai mengembangkan gagasan hak-hak manusia dibidang kesehatan, yaitu hak dasar pemeliharaan kesehatan (the right to healthcare) dan hak untuk menentukan nasib sendiri (the right on selfdetermination) kemudian dalam perkembangannya hak dasar tersebut akomodasi dalam Pasal 25 ayat (1) United Nations Universal Declaration of Human Right. Atas dasar pemikiran tersebut maka saat ini pola hubungan antara dokter dan pasien sudah berkembang menjadi pola partnership di dalam pola ini, hubungan antara dokter dan pasien adalah seimbang, pasien tidak lagi bersifat pasif dan menyerahkan segalanya kepada dokter, melainkan terdapat hubungan aktif antara dokter dan pasien sehingga hubungan tersebut disebut partnership.

Adanya perubahan tersebut dimaknai dengan semakin berkembangnya pengetahuan dan kesadaran masyarakat terhadap tanggungjawab akan kesehatan individu, dengan demikian hal tersebut mengakibatkan pergeseran paradigm yang berlaku dari kepercayaan yang semula tertuju kepada kemampuan dokter

\footnotetext{
${ }^{6}$ Munandar Wahyudin Suganda, Hukum Kedokteran, Bandung, Alpa Beta, 2017, hlm. 33.

${ }^{7}$ Guwandi, Informed Consent and Informed Refusal, Jakarta, Fakultas Kedokteran Universitas Indonesia, 2006, hlm. 70 .

${ }^{8}$ Mustajab, Analisis Yuridis Hubungan Hukum Antara Dokter Dan Pasien Dalam Pelayanan Kesehatan, Jurnal Ilmu Hukum Legal opinion. No. 4. Vol. 1 Tahun 2013, hlm. .2.
} 
secara pribadi dan pada akhirnya beralih kepada kemampuan penguasaan ilmu secara professional dari dokter yang bersangkutan. Atas dasar tersebut muncullah kesadaran maasyarakat untuk menutut. Perekembangan hubungan dokter dengan pasien digambarkan oleh Dassen bahwa, pasien pergi kedokter karena merasakan sesuatu yang membahayakan kesehatannya sehingga memerlukan tindaka dokter sebagai seseorang yang memiliki kelebihan karena seorang dokter mampu mengobati dan pasien pergi kedokter karena mengetahui dirinya sakit dan dokter dipandang mampu untuk menyembuhkan, selanjutnya adalah pasien pergi kedokter untuk mendapat pemeriksaan yang intensif dan mengobati penyakit. ${ }^{9}$

Dalam Pasal 50 Undang-Undang No. 29 Tahun 2004 tentang Peraktik Kedokteran sudah dijelaskan bahwa batasan batasan kemampuan minimal yang harus dikuasai oleh seorang dokter dalam menjalankan peraktik profesinya secara mandiri yang dibuat oleh organisasi profesi adalah knowledge, skill, and professional attitude, yang berarti pengetahuan, keterampilan, dan sikap. ${ }^{10}$

Profesi dokter merupakan profesi yang membutuhkan penguasaan pengetahuan dan keterampilan klinis yang pelaksanaannya disesuaikan dengan aturan dan etika yang berlaku. Dokter harus memiliki skill atau berpikir sistematis, kemampuan ini berhubungan dengan penguraian suatu masalah yang teratur dan logis agar dokter dapat mengetahu penyebab dari masalah tersebut, professional attitude yang dimiliki oleh seorang dokter merupakan sikap yang tepat, rasa hormat, dan memiliki kemampuan untuk memlakukan pekerjaannya dengan baik sesuai dengan standar yang ada. Seorang dokter yang profesional harus memprioritaskan kesejahteraan pasien, bahkan diatas kepentingan pribadi mereka sendiri, perilaku profesional menjadi bagian kompetensi yang wajib dikuasai seorang dokter. Penguasaan kompetensi yang mencakup sikap, pengetahuan, keterampilan, secara seimbang akan memungkinkan seorang dokter menjadi berkompeten dan dapat menunjukkan kinerja optimal.

Tindakan medis yang dilakukan oleh dokter terhadap pasien haruslah sesuai dengan kewenangan kompetensi yang diperoleh pada masa pendidikan kedokteran, seorag dokter umum tidak membatasi praktek mereka pada penyakit tertentu atau metode pengobatan tertentu. Dokter umum dituntut mampu untuk melakukan managemen sumberdaya dan pasilitas ditempat kerjanya, serta mampu memberi perotolongan pertama pada pasien gawat darurat, serta bisa melakukan pembedahan kecil serta bertanggungjawab untuk memberikan hlm. 55.

${ }_{9}^{9}$ Muntaha, Hukum Pidana Malpraktik Pertanggungjawaban dan Penghapus Pidana, Jakarta, Sinar Grafika. 2017,

10 Undang-Undang No. 29 Tahun 2004 tentang Peraktik Keokteran. 
perawatan awal dan memastikan kondisi pasien stabil, serta mencegah komplikasi berlanjut. Pasien yang menderita penyakit tertentu akan dirujuk oleh dokter umum ke dokter spesialis untuk mendapatkan penanganan yang tepat. Sedang kewenangan kompetensi dokter spesialis (specialist medical doctors) adalah dokter yang mendiagnosa, menyembuhkan, dan mencegah penyakit, cedera, dan kelainan fisik serta mental lainnya dan menjaga kesehatan umum pada manusia melalui penyelenggaraan dan prosedur pengobatan modern, dengan demikian dokter spesialis mengkhususkan pada kategori penyakit tertentu, tipe pasien atau metode pengobatan, dan dapat melakukan pendidikan dan riset pada area spesialisasi yang mereka pilih. Berdasarkan dengan hal itu secara jelas kewenangan dan kompetensi seorang dokter dalam memberikan pelayanan kesehatan sesuai dengan kompetensi yang dimilikinya selama masa pendidikan atau pelatihan tambahan yang diperolehnya. Dengan demikian bahwa kompetensi dokter adalah kemampuan pengetahuan serta keterampilan seorang dokter dalam melakukan pemeriksaan ataupun pengobatan kepada pasien.

\section{Rumusan Masalah}

Berdasarkan latar belakang yang diuraikan sebelumnya, maka rumusan maslah dalam penelitian ini yaitu, apakah dokter diperbolehkan melakukan tindakan medis yang bukan kewenangan kompetensi profesinya?

\section{Tujuan Penelitian}

Berdasarkan rumusan masalah yang disebutkan sebelumnya, maka tujuan penelitian dalam penelitian ini yaitu untuk mengetahui dokter diperbolehkan atau tidak diperbolehkan melakukan tindakan medis yang bukan kewenangan kompetensi profesinya.

\section{Metode Penelitian}

Untuk mendapatkan bahan dan alur pikir yang bersifat yuridis guna menguraikan penelitian terkait batasan dokter mengambil tindakan medis yang bukan kewenangan kompetensi profesinya, maka jenis penelitian ini tergolong penelitian normatif, yaitu penelitian hukum yang dilakukan dengan cara mengkaji ketentuan hukum mengenai batasan dokter dalam mengambil tindakan medis yang bukan kompetensi profesinya. Selain itu dilakukan juga penelitian kepustakaan dengan cara mempelajari terhadap hal-hal yang bersifat teoritis yang menyangkut asas hukum, pandangan serta peraturan perundang-undangan yang terkait. Adapun bahan hukum primer dalam penelitian ini adalah a. Undang- 
Undang Nomor. 29 Tahun 2004 tentang Peraktik Kedokteran; b. Undang-Undang Nomor. 20 Tahun 2003 tentang Pendidikan Kedokteran; c. Undang-Undang Nomor. 36 Tahun 2009 tentang Kesehatan; dan d. Undang-Undang Nomor. 44 Tahun 2009 tentang Rumah Sakit. Bahan hukum sekunder dalam penelitian ini yaitu hasil penelitian yang terdahulu dan literatur-literatur yang ada serta bukubuku kepustakaan yang berhubungan dengan ketentuan hukum pidana positif Indonesia apabila ada dokter yang melakukan tindakan medis yang bukan kompetensi profesinya. Sedangkan bahan hukum tersier dalam penelitian ini merupakan bahan hukum yang memberikan petunjuk terhadap bahan hukum primer dan bahan hukum sekunder dalam bentuk tulisan, jurnal, kamus yang berkaitan dengan penelitian ini.

\section{Hasil Penelitian dan Pembahasan}

\section{Batasan Dokter Mengambil Tindakan Medis yang Bukan Kewenangan Kompetensi Profesinya}

Kewenangan profesi dokter merupakan hak dan kekuasaan yang dipunyai untuk melakukan sesuatu tindakan medis kepada pasiennya dalam upaya pencegahan penyakit, peningkatan kesehatan, pengobatan penyakit dan pemulihan kesehatan. Seorang dokter yang melakukan profesi medis harus mengikuti suatu masa pendidikan yang cukup panjang, dari hasil pendidikan itu sorang dokter memiliki suatu kualifikasi keilmuan dan keterampilan yang jauh melebihi orang awam, dengan kualifikasi keilmuan dan keterampilan khusus yang dimiliki tersebut, para pengemban profesi kesehatan dapat melakukan profesi medis. ${ }^{11}$ Profesi kedokteran merupakan profesi yang membutuhkan penguasaan sejumlah pengetahuan dan keterampilan klinis termasuk di dalamnya adalah standar yang tinggi akan kebiasaan dan perilaku yang tepat, oleh karena itu seorang dokter usaha pembelajaran atau pendidikan sangat penting sebelum menjalankan profesi tersebut yang nantinya akan memperaktikkan perilaku profesional sesuai yang diharapkan. ${ }^{12}$

Penyelenggaraan peraktik kedokteran setiap dokter mempunyai kewenangan dan kompetensi yang diperoleh atau yang dimiliki pada masa proses pendidikan, karena itu berkaitan dengan kewenangan serta kompetensi dokter baik itu dokter umum maupun dokter spesialis merupakan totalitas pengetahuan yang dimiliki setiap dokter, artinya dokter umum dan dokter spesialis memiliki tingkat

11 Marcel Seran, Anna Mariah Wahyu Setyowati, Kesalahan Profesional Dokter Dan Urgensi Peradilan Profesi, Jurna Hukum Pro Justicia. Vol. 24. No. 4/ 2006.

12 Cici Bahkti Purnamasari, Mora Claramita, Pembelajaran Profesionalisme Kedokteran Dalam Persepsi Instruktur Dan Mahasiswa, Juenal Pendidikan Kedokteran indonesia, Vol. 4. No. 1. Maret 2015, hlm. 1. 
pengetahuan yang berbeda dalam menangani pasiennya, maupun penalaran klinis yang diperoleh pada masa pendidikan kedokteran.

Berdasarkan hasil wawancara penulis dengan Sekretaris Ikatan Dokter Indonesia Provinsi Riau Abdullah Qayyum, menyatakan bahwa tindakan seorang dokter sebelum mengambil prosedur tindakan medis kepada pasiennya terlebih dahulu dilakukan anamnesis atau wawancara menanyakan secara langsung mengenai keluhan-keluhan penyakit dan riwayat-riwayat penyakit maupun obat yang dikomsumsi sebelumnya, kalau pasien dalam keadaan tidak sadar hal tersebut ditanyakan kepada pihak keluarganya, agar pasien atau keluarganya mendapatkan informasi masalah tindakan medis yang akan dilakukan dan mendapatkan pemeriksaan jasmani atau pemeriksaan fisik pasien dimulai dari keluhan penyakit di bagian anggota tubuh agar menemukan tandatanda penyakit yang diderita oleh pasien, kemudian seorang dokter akan mencatat keluhan-keluhan pasien berdasarkan pemeriksaan tersebut, dan selanjutnya juga bisa dilakukan pemeriksaan penunjang misalnya pemeriksaan laboratorium, pemeriksaan rongsen hal itu dilakukan untuk memperkuat temuan dari penyakit pasien. Kemudian seluruh data akan dikumpulkan untuk dianalisa, dokter akan mencoba mencari kesimpulan dengan mengambil satu diagnosa untuk menentukan penyakit pasien. Sesudah melakukan diagnosa maka dilakukanlah tindakan medis terhadap pasien ataupun pemberian obat-obatan, tergantung kepada kondisi pasien yang datang pada saat pemeriksaan untuk dilaksanakan tindakan medis yang sesuai dengan standar prosedur. ${ }^{13}$ Setiap dokter mepunyai kewenangan dan kompetensi dalam melakukan tindakan medis terhadap pasiennya, kompetensi dokter bergantung kepada pengakuan atas apa yang diperolehnya selama proses pendidikan dan proses setelah menyelesaikan pendidikan di fakultas kedokteran. Dan adakalanya seorang dokter mendapatkan pelatihan tambahan untuk mendapatkan kompetensi tersebut. Maka dari pada itu kompetensi bergantung kepada tingkatan dan proses yang didapat pada saat pendidikan. Hal itu adanya perbedaan antara dokter umum dan dokter spesialis. Dalam keadaan normatif profesi kedokteran seorang dokter akan menjalankan kompetensinya sesuai dengan yang didapatkannya pada saat proses pendidikan maupun kompetensi tambahan yang didapatkannya pada saat pelatihanpelatihan khusus. ${ }^{14}$ Demikian juga hasil wawancara penulis dengan Salah satu Dosen Hukum Kesehatan Universitas Islam Indonesia dr. Suryono. Dalam keadaan tertentu sorang dokter dapat melakukan tindakan medis yang bukan

${ }^{13}$ Hasil wawancara Bersama Sekretaris Ikatan Dokter Indonesia Wilayah Riau dr, Abdullah Qayyum.

${ }^{14}$ Ibid. 
kompetensi profesinya ketika seorang dokter tersebut diberikan kompetensi atau pelatihan khusus mengenai penyakit tertentu, misalnya disuatu tempat yang tidak memiliki dokter spesialis maka pihak rumah sakit memberikan pelatihan khusus kepada dokter umum mengenai suatu penyakit tertentu dan tentunya dokter tersebut memiliki kewenangan atau kompetensi tambahan dan memiliki sertifikat, ketika seorang dokter umum pindah ketempat yang lain maka kewenangan tersebut tidak berlaku. ${ }^{15}$

Ada dua bentuk yang dapat dibedakan, namun mempunyai satu kesatuan yang tidak dapat dipisahkan satu sama lain, pertama, kewenangan yang berdasarkan keahlian yang dimiliki seorang dokter, kewenangan ini merupakan kewenangan keahlian atau sering disebut dengan kewenangan materil, yang semata-mata melekat pada individu seorang dokter, kedua, kewenangan menurut peraturan perundang-undangan, atau merupakan kewenangan formil.

Berdasarkan analisis penulis bahwa sebelum seorang dokter berpraktik maupun melakukan tindakan medis kepada pasiennya. Seorang dokter mempunyai kewajiban untuk memenuhi kewenangan formil yang merupakan kewenangan yang didasarkan pada Undang-Undang Nomor 29 Tahun 2004 Tentang Peraktik Kedokteran pada Pasal 29 ayat (1) dan Pasal 36. Adapun pada Pasal 29 ayat (1) yang menyatakan bahwa setiap dokter dan dokter gigi yang melakukan peraktik kedokteran di Indonesia wajib memiliki surat tanda registrasi dokter dan surat registrasi dokter gigi. Ada beberapa syarat yang harus dipenuhi untuk memperoleh Surat Tanda Regitrasi, adapun syarat-syarat yang harus dipenuhi adalah, memiliki ijazah dokter, dokter spesialis dokter gigi, dokter gigi spesialis, mempunyai surat pernyataan telah mengucapkan sumpah janji dokter, memiliki surat keterangan sehat pisik dan mental, memiliki sertifikat kompetensi dan yang terakhir adalah, membuat surat pernyataan akan mematuhi dan melaksanakan ketentuan etika profesi. Surat Tanda Registrasi (STR) diterbitkan oleh Konsil kedokteran dan berlaku selama Lima tahun dan diregistrasi ulang setiap Lima tahun sekali. Pengaturan berikutnya pada Pasal 36 Undang-Undang Nomor 29 Tahun 2004 tentang Peraktik Kedokteran menyatakan bahwa setiap dokter dan dokter gigi yang melakukan peraktik kedokteran di indonesia wajib memiliki surat izin peraktik. Surat izin peraktik ini dikeluarkan oleh pejabat kesehatan yang berwenang di kabupaten/kota, tentunya surat izin peraktik ini dikeluarkan oleh dinas kesehatan yang mempunyai wewenang khusus dimana seorang dokter yang melakukan peraktik kedokteran. Artinya ketika seorang dokter yang ingin mendapatkan surat izin peraktik mempunyai persyaratan-

${ }^{15}$ Hasil Wawancara Penulis Via Watshap Dengan Dosen Hukum Kesehatan Universitas Islam Indonesia, dr. Suryono. 
persyaratan yaitu, memiliki surat tanda registrasi dokter maupun dokter gigi, mempunyai tempat peraktik dan memiliki rekomendasi dari organisasi profesi. Surat tanda registrasi dan surat izin peraktik merupakan satu kesatuan yang harus dimiliki seorang dokter dalam melaksanakan peraktik kedokteran.

Sehubungan dengan yang telah penulis paparkan diatas bahwa kewenanngan yang harus dimiliki seorang dokter dalam melaksanakan peraktik kedokteran serta melakukan tindakan medis harus memiliki dua kewenangan yang telah penulis jelaskan diatas tersebut, ketika seorang dokter dalam melaksanakan peraktik kedokteran serta melakukan tindakan medis tidak memiliki kewajiban atas kewenangan yang diharuskan oleh Undang-Undang memiliki Surat Tanda Registrasi (STR) dan Surat Izin Peraktik (SIP) Maka dokter tersebut melanggar ketentuan Undang-Undang dan mendapatkan sanksi denda atas perbuatannya. Sebagaimana yang diatur di dalam Undang-Undang Nomor 29 Tahun 2004 tentang Peraktik Kedokteran Pada Pasal 75 dan Pasal 76. Pada Pasal 75 menyatakan bahwa "setiap dokter atau dokter gigi yang dengan sengaja melakukan peraktik kedokteran tanpa memiliki Surat Tanda Registrasi sebagaimana yang dimaksud pada Pasal 29 ayat (1) dipidana penjara paling lama 3 tahun atau denda paling banyak Rp. 100.000.000.00 (ketentuan pidana penjara telah dicabut oleh Mahkamah Konstitusi). Seterusnya berdasarkan pada Pasal 76 yang menyatakan bahwa "setiap dokter atau dokter gigi yang dengan sengaja melakukan peraktik kedokteran tanpa memiliki surat izin peraktik sebagaimana yang dimaksud dalam Pasal 36 dipidana dengan pidana penjara paling lama tiga tahun atau denda paling banyak Rp. 100.000.000.00 ketentuan pidana penjara telah cabut oleh Mahkamah Konstitusi.

Standar profesi medis yang kedua merupakan kemampuan rata-rata, mengenai kemampuan rata-rata tersebut adalah tiga kemampuan yang telah disebutkan di dalam penjelasan Pasal 5 Undang-Undang Nomor. 29 Tahun 2004, yaitu kemampuan knowledge, kemampuan dalam skill, dan kemampuan dalam professional attitude, dari tiga unsur tersebut tidak mudah untuk ditentukan, banyak faktor yang mempengaruhinya, faktor tersebut merupakan berdasarkan pengalaman dan berdasarkan banyaknya atau seringnya peraktik, lamanya peraktik, daerah peraktik, fasilitas peraktik, dan pergaulan sesama kolega profesi, dengan demikian berdasarkan alasan tersebut, walaupun mungkin standar profesinya sama namun penerapannya pada kasus-kasus dugaan malpraktik tidak saya dan harus disesuaikan dengan keadaan dan faktor-faktor tersebu, oleh karenanya, suatu kesalahan dapat dipandang wajar, akan tetapi tidak dapat diremehkan kesalahan yang sama oleh dokter yang sudah lama berpraktik di kota 
dirumah sakit besar. Wajar pula hukum mempertimbangkan keadaan khusus setiap dokter dan tidak menyamaratakan semua dokter, salah satu pertimbangan kelalaian dalam hukum adalah didasarkan pada ukuran obyektif (ajaran culpa obyektif). Pada keadaan-keadaan dan situasi yang sama dengan si pembuat yang dianggap lalai tersebut, maka untuk mengukur kelalaian seorang dokter yang berperaktik dikota besar, harus diukur dengan kemampuan rata-rata dokter yang berperaktik di kota besar.

Standar profesi yang ketiga merupakan ketelitian yang umum, kewajiban dokter dalam kontrak terapeutik yaitu berbuat segala sesuatu dalam peraktik kedokteran secara cermat, teliti, dan penuh kehati-hatian, dan tidak ceroboh, kecermatan dan ketidak hati-hatian diukur secara umum, artinya keteltian dan kehati-hatian dokter dalam melaksanakan tindakan medis yang sama. Dalam hal melaksanakan tindaka medis yang sama bagi semua dokter haruslah memiliki dan menjalankan ketelitan dan keseksamaan yang sama. Dengan demikian syarat ketelitian yang umum dari dokter sesuai dengan acara culpa obyektif, yang mengukur ada tidaknya culpa pada syarat-syarat yang sama dari orang lain baik keadaannya maupun situasi yang sama dalam melakukan perbuatan yang sama sebagaimana yang dilakukan oleh si pembuat. Ukuran kecermatan dan ketelitan dalam standar prosedur harus bertitik tolak pada kecermatan dan kehati-hatian yang sama dalam melakukan tindakan medis yang sama, suatu tindakan yang seksio sesarea. Tingkat ketelitiannya harus ditentukan dan diukur secara umum yang dilakukan oleh dokter keahlian yang sama dalam melakukan seksio sesarea. Tidak diukur tingkat ketelitiannya yang sama dengan dokter lain dalam melakukan tindakan medis lainnya.

Peraturan perundang-undangan menentukan standar profesi medis dapat diketahui dari Pasal 51 Huruf (a) Undang-Undang Nomor 29 Tahun 2004 Juncto Pasal 58 ayat (1) Huruf (a) Undang-Undang Nomor 36 Tahun 2009, dengan jelas menyatakan yaitu "setiap dokter atau dokter gigi dalam melaksanakan peraktik kedokteran mempunyai kewajiban memberikan pelayanan medis sesuai dengan standar profesi, standar prosedur operasional serta kebutuhan medis pasien". Secara normatif profesi kedokteran dalam melaksanakan peraktik kedoktera, standar profesi dan standar prosedur operasional dan kebutuhan medis pasien merupakan norma hukum yang mengikat perbuatannya, maka daripada itu baik sebagai pembatasan dari segala perbuatan yang sekaligus sebagai pedoman atau pemandu, dan sebagai pembatasan artinya setiap tindakan tidak boleh keluar atau melanggar dari standar profesi dan standar prosedur. Sebagai alat pemandu artinya bahwa setiap langka harus sesuai atau sama dengan norma dalam standar profesi. Undang-Undang Nomor 36 Tahun 2004 tentang Kesehatan Pasal 24 ayat 
(1) dan (2) menyatakan bahwa "Tenaga kesehatan sebagaimana dimaksud dalam Pasal 23 harus memenuhi ketentuan kode etik, standar profesi, hak pengguna pelayanan kesehatan, standar pelayanan, dan standar prosedur operasional" dan ayat (2) "ketentuan mengenai kode etik dan standar profesi sebagaimana yang dimaksud pada ayat (1) diatur oleh organisasi profesi.

Batasan dokter dalam melakukan tindakan medis yang bukan kewenangan kompetensi profesinya diatur di dalam berbagai regulasi Baik Undang-Undang Nomor 20 Tahun 2013 tentang Pendidikan Kedokteran, Undang-undang Nomor 29 Tahun 2004 tentang Peraktik Kedokteran, Undang-Undang Nomor 36 Tahun 2009 tentang Kesehatan dan Undang-Undang Nomor 44 Tahun 2009 tentang Rumah Sakit

Undang-Undang Nomor 20 Tahun 2013 tentang Pendidikan Kedokteran pada Pasal 39 ayat (1) menjelaskan bahwa "mahasiswa program dokter layanan primer, dokter spesialis-subpesialis, dan dokter gigi spesialis-subpesialis harus mengikuti uji kompetensi dokter layanan primer, dokter spesialis-subspesialis, dan dokter gigi spesialis-subspesialis yang bersifat nasional dalam rangka memberi pengakuan pencapaian kompetensi profesi dokter layanan primer, dokter spesialis-subspealis- dan dokter gigi spesialis-subspeialsis. Berdasarkan pasal tersebut menjelaskan bahwa kompetensi dokter merupakan kemampuan minimal dalam bidang pengetahuan, keterampilan, serta sikap dan perilaku profesional untuk dapat melakukan kegiatan dimasyarakat. Dengan demikian, jelaslah bahwa setelah lulus dari uji kompetensi dokter, seorang dokter menyelenggarakan peraktik kedokteran dan melakukan tindakan medis sesuai dengan kewenangan kompetensinya profesinya. kompetensi tidak hanya didapatkan seorang dokter melalui pendidikan kedokteran akan tetapi kompetensi itu didapatkan melalui pelatihan-pelatihan yang diberikan kepada dokter tersebut, karena tidak semua fasilitas pelayanan kesehatan atau rumah sakit memiliki dokter spesialis, adakalanya rumah sakit yang berada didaerah terpencil yang tidak memiliki dokter spesialis, karena itu dokter umum diberikan pelatihan khusus agar memiliki kewenangan atau komptensi untuk penyakit tertentu. Artinya ketika seorang dokter gigi umum melakukan tindakan medis yang bukan kewenangan kompetensinya dapat diperbolehkan ketika dokter tersebut memiliki sertifikat kompetensi yang didapatkan pada saat pendidikan atau pelatihan khusus, karena kompetensi dokter gigi umum tentu berbeda dengan kompetensi dokter gigi spesialis bedah mulut, pada perinsipnya seorang dokter umum tidak mempunyai kapasitas atau keahlian yang dimiliki untuk melakukan tindakan medis bedah mulut, karena pada saat peroses pendidikan kewenangan kompetensi bedah 
mulut tidak didapatkan dokter tersebut, dan yang mempunyai kewenangan untuk melakukan bedah mulut adalah dokter spesialis bedah mulut, akan tetapi dokter umum mempunyai kapasitas atau keahlian untuk melakukan tindakan medis bedah mulut apabila seorang dokter umum telah mendapatkan pendidikan lanjutan atau pealtihan khusus mengenai bedah mulut dan mendapatkan sertifikat kompetensi maka dokter umum tersebut mempunyai kewenangan untuk melakukan operasi bedah mulut tersebut.

Tenaga kesehatan termasuk dalam hal ini profesi kedokteran dalam menjalankan praktik kedokteran harus sesuai dengan kewenangan yang didasarkan pada kompetensi yang dimilikinya, sebagaimana yang terdapat di dalam Undang-Undang Nomor 29 Tahun 2004 tentang Peraktik Kedokteran pada Pasal 27 yang menyatakan Pendidikan dan pelatihan kedokteran atau kedokteran gigi, untuk memberikan kompetensi kepada dokter atau dokter gigi, dilaksanakan sesuai dengan standar pendidikan profesi kedokteran atau kedokteran gigi. Dan Pasal 51 yang menjelaskan bahwa “dokter dan dokter gigi dalam menjalankan peraktik kedokteran mempunyai kewajiban pada huruf (a) menjelaskan bahwa memberikan pelayanan medis sesuai denganstandar profesi dan standar prosedur operasional serta kebutuhan medis pasien. Huruf (b) menjelaskan merujuk pasien kedokter atau dokter gigi lain yang mempunyai keahlian atau kemampuan yang lebih baik, apabila tidak mampu melakukan suatu pemeriksaan atau pengobatan. Huruf (e) menambah ilmu pengetahuan dan mengikuti perkembangan kedokteran atau kedokteran gigi. Jelahlah pada pasal tersebut bahwa tindakan dokter yang bukan pada kewenangan kompetensi profesinya harus merujuk kepada dokter yang mempunyai kompetensi terhadap penyakit tersebut. Karena kurangnya ilmu pengetahuan serta keterampilan pada saat proses pendidikan kedokteran membuat dokter tersebut mempunyai kompetensi yang berbeda dengan dokter lainnya dan dilakukukan uji kompetensi atas pencapaiannya pada saat proses pendidikan kedokteran. Dengan demikian bahwa dokter tersebut bisa melakukan tindakan medis walaupun bukan kompetensi profesinya dengan persyaratan telah mengikuti pendidikan dan pelatihan tambahan yang didapatkannya.

Undang-Undang Nomor 36 Tahun 2009 tentang Kesehatan pada Pasal 69 ayat (1) yang berbunyi "beda plastik dan rekonstruksi hanya boleh dilakukan oleh tenaga kesehatan yang mempunyai kewenangan dan keahlian terhadap itu. Berdasarkan pasal tersebut jelahlah bahwa penanganan khusus untuk melakukan tindakan medis tertentu hanya boleh dilakukan kepada dokter yang mempunyai kewenangan atas penyakit tersebut, dengan demikian bahwa apabila seorang tenaga medis yang melakukan tindakan medis yang bukan pada kompetensi 
tersebut haruslah bahwa tenaga medis tersebut menlanjutkan pendidikan kedokteran dan medapatkan pelatihan tambahan atas penyakit tesebut yang diselenggarakan oleh fakultas kedokteran maupun yang disediakan oleh rumah sakit, apabila seorang dokter yang melakukan tindakan medis yang bukan pada kewenangan kompetensinya dan tidak mempunyai sertifikat komptensi atas penyakit yang telah ditentukan, maka tenaga medis tersebut tidak semestinya melakukan tindakan itu. Pasal 30 ayat (2) Undang-Undang Kesahatan Juga menjelaskan bahwa dalam pelayanan kesehatan ada tiga macam fasilitas pelayanan kesehatan yaitu, fasilitas kesehatan tingkat pertama yang merupakan pelayanan kesehatan dasaryang diberikan oleh fasilitas pelayanan kesehatan tingkat pertama, dan fasilitas pelayanan kesehatan tingkat kedua, yang merupakan pelayanan kesehatan yang spesialistik yang dilakukan oleh dokter spesialis atau dokter gigi spesialis yang menggunakan pengetahuan dan teknologi kesehatan spesialistik, fasilitas kesehatan tingkat ketiga adalah pelayanan kesehatan yang sub-spesialistik yang dilakukan oleh dokter sub-spesialis atau dokter gigi subspesialis yang menggunakan pengetahuan dan teknologi kesehatan subspeasistik. Dengan demikian bahwa seorang dokter dapat merujuk pasien kefasilitas pelayanan kesehatan tingkat lanjutan dan wajib melakukan sistem rujukan dengan mengacu pada peraturan perundang-undangan.

Berdasarkan Peraturan Konsil Kedokteran Indonesia Nomor 44 Tahun 2011 tentang Disiplin Profesional Dokter dan Dokter gigi Bab II terdiri dari 28 bentuk pelanggaran, akan tetapi penulis membatasi sesuai dengan topik pembahasan yang penulis kaji terkait kewengan kompetensi profesi dokter terdapat bentuk pelanggaran disiplin profesional dokter dan dokter gigi yaitu: a. Melakukan peraktik kedokteran yang tidak kompeten; dalam menjalankan asuhan medis atau asuhan klinis kepada pasien, dokter dan dokter gigi harus bekerja dalam batas-batas kompetensinya, baik dalam penegakan diagnosis maupun dalam penatalaksanaan pasien, setiap dokter dan dokter gigi harus memiliki pengetahuan dan keterampilan yang diperlukan dalam melakukan peraktik kedokteran. b. Tidak merujuk pasien kepada dokter atau dokter gigi lain yang memiliki kompetensi yang sesuai. 1) Dalam situasi dimana penyakit atau kondisi pasien di luar kompetensinya karena keterbatasan pengetahuan, keterbatasan keterampilan, ataupun keterbatasan peralatan yang tersedia, maka dokter dan dokter gigi wajib menawarkan pasien untuk dirujuk atau di konsultasikan kepada dokter atau dokter gigi lain atau sarana pelayanan kesehatan lain yang lebih sesuai. 2) Upaya perujukan dapat tidak dilakukan, apabila situasi yang terjadi antara lain adalah, pertama, kondisi pasien tidak memungkinkan pasien 
untuk dirujuk, kedua, keberadaan dokter atau dokter gigi lain atau sarana kesehatan yang lebih tepat, sulit dijangkau atau sulit didatangkan dan atau ketiga, atas kehendak pasien. c. Mendelegasikan pekerjaan kepada tenaga kesehatan tertentu yang tidak memiliki kompetensi untuk melaksanakan pekerjaan tersebut. 1) Dokter dan dokter gigi dapat mendelegasikan tindakan atau prosedur kedokteran tertentu kepada tenaga kesehatan tertentu yang sesuai dengan ruang lingkup keterampilan mereka. 2) Dokter dan dokter gigi harus yakin bahwa tenaga kesehatan yang menerima pendelegasian tersebut memiliki kompetensi untuk itu. 3) Dokter dan dokter gigi tetap bertanggungjawab atas penatalaksanaan pasien yang bersangkutan. d. Menyediakan dokter atau dokter gigi penganti sementara yang tidak memiliki kompetensi dan kewenangan yang sesuai atau tidak melakukan pemberitahuan perihal pengantian tersebut. 1) Bila dokter atau dokter gigi yang berhalangan menjalankan peraktik kedokteran maka dapat menyediakan dokter atau dokter gigi pengganti yang memiliki kompetensi sama dan memiliki surat izin peraktik. 2) Dalam kondisi keterbatasan tenaga dokter atau dokter gigi dalam bidang tertentu sehingga tidak memungkinkan tersedianya dokter atau dokter gigi pengganti yang memiliki kompetensi yang sama, maka, dapat disediakan dokter atau dokter gigi penggati lainnya. 3) Surat izin peraktik dokter atau dokter gigi pengganti tidak haru surat izin peraktik di tempat yang harus digantikan. 4) Ketidakhadiran dokter atau dokter gigi bersangkutan dan kehadiran dokter atau dokter gigi pada saat dokte atau dokter gigi berhalangan peraktik, harus diinformasikan kepada pasien secara lisan atau tertulis ditempat peraktik dokter. 5) Jangka waktu penggantian ditentukan sesuai dengan ketentuan peraturan perundang-undangan yang berlaku atau etika profesi.

Berdasarkan peraturan konsil kedokteran tersebut bahwa dalam penyelenggaran peraktik kedokteran seorag dokter maupun dokter gigi harus bekerja sesuai dengan batas-batas kompetensi yang dimilki, dan seorang dokter harus memiliki pengetahuan, keterampilan yang diperlukan dalam melakukan peraktik kedokteran. Dengan demikian bahwa apabila seorang dokter menangani suatu penyakit diluar kompetensinya, disebabkan kurangnya pengetahuan serta keterampilan ataupun kurangnya peralatan yang tersedia, maka seorang dokter maupun dokter gigi wajib menawarkan kepada pasien untuk dilakukan rujukan atau konsultasi kepada dokter atau dokter gigi lain yang mempunyai kompetensinya serta pelayanan kesehatan lain yang sesuai dengan kebutuhan medis pasien.

Undang-Undang Nomor 44 Tahun 2009 tentang Rumah sakit pada Pasal 29 ayat (1) huruf j menyatakan bahwa melaksanakan sistem rujukan, berdasarkan 
pasal tersebut secara jelas bahwa apabila pihak rumah sakit tidak mempunyai dokter yang mempunyai kewenangan kompetensi dibidang penyakit tertentu maka pihak rumah sakit melaksanakan sistem rujukan kepada rumah sakit lainnya yang mempunyai dokter spesialis dibidang penyakti tertentu. Dengan demiian, bahwa seorang dokter mempunyai batasan-batasan penanganan penyakit tertentu yang tidak boleh dilakukan oleh dokter yang tidak mempunyai kompetensi profesinya, apabila dokter tersebut mendapatkan pasien yang bukan kewenangan kompetensinya maka dokter tersebut harus melakukan rujukan kepada dokter yang mempunyai kompetensi itu. Terhadap yang telah penulis paparkan diatas terdapat pengecualian bahwa dalam keadaan kegawatdaruratan semua fasilitas pelayanan kesehatan maupun seorang dokter yang tidak mempunyai kompetensi dibidang penyakit itu, diwajibkan oleh Undang-Undang untuk memberikan pertolongan pertama sebagaimana yang telah diatur di dalam Undang-Undang Nomor 36 Tahun 2009 tentang Kesehatan pada Pasal 32 ayat (1) dan (2) yang menyakan bahwa "dalam keadaan darurat, fasilitas pelayanan kesehatan, baik pemerintah maupun swasta, wajib memberikan pelayanan kesehatan bagi penyelamatan nyawa pasien dan pencegahan kecacatan terlebih dahulu". Ayat (2) yaitu "dalam keadaan darurat, fasilitas pelayanan kesehatan baik pemerintah maupun swasta dilarang menolak pasien atau meminta uang muka".

\section{Penutup}

Kewenangan dalam penyelenggaraan peraktik kedokteran di dalam Undang-Undang Nomor 29 Tahun 2004 tentang Peraktik Kedokteran, setiap dokter terlebih dahulu wajib mempunyai Surat Tanda Registrasi (STR) dan Surat Izin peraktik (SIP). Ketika kedua hal itu telah terpenuhi maka setiap dokter berhak melakukan peraktik kedokteran sesuai dengan kewenangan kompetensi profesinya. Setiap dokter mempunyai kompetensi yang berbeda dalam melakukan penyelenggaraan peraktik kedokteran dan atau melakukan tindakan medis kepada pasiennya. Di dalam Pasal 51 huruf b Undang-Undang Nomor 29 Tahun 2004 tentang Peraktik Kedokteran. Menjelaskan bahwa apabila tidak mampu melakukan pemeriksaan atau pengobatan tentunya pasien dirujuk kepada seorang dokter yang mempunyai keahlian atau kemampuan yang lebih baik. Penanganan khusus terhadap tindakan medis juga terdapat di dalam Pasal 69 ayat (1) Undang-Undang Nomor 36 Tahun 2009 tentang Kesehatan yang menyatakan bahwa beda plastik dan rekonstruksi hanya boleh dilakukan oleh tenaga kesehatan yang mempunyai kewenangan dan keahlian terhadap itu. 
Pengemban profesi dokter dalam menjalankan peraktik kedokteran haruslah melaksanakan profesinya secara profesional serta mengikuti pedoman yang telah ditentukan baik standar profesi maupun standar prosedur operasional dokter serta kebutuhan medis pasien, dalam proses tindakan medis yang diberikan oleh dokter haruslah sesuai kewenangan kompetensinya yang diperoleh pada saat pendidikan kedokteran serta bekerja secara profesional sesuai dengan pengetahuan dan keterampilan seorang dokter, apabila tidak mampu melakukan pemeriksaan ataupun pengobatan sebagaimana yang diatur oleh undang-undang untuk merujuk pasien tersebut kepada dokter lain, atau melimpahkan kewenangan kepada dokter lain yang sesuai dengan kompetensi dokter tersebut.

\section{Daftar Pustaka}

\section{Buku}

Guwandi, Informed Consent and Informed Refusal, Fakultas Kedokteran Universitas Indonesia, Jakarta, 2006.

Machli, Riyadi, Teori Iknemook dalam Mediasi Malapraktik Medik, Prenamedia, Jakarta, 2018.

Muntaha, Hukum Pidana Malpraktik Pertanggungjawaban dan Penghapus Pidana, Sinar Grafika, Jakarta, 2017.

Siswati, Sri, Etika dan Hukum Kesehatan dalam Perspektif Undang-Undang Kesehatan Rajawali Press, Jakarta, 2015.

Suganda Munandar, Wahyudin, Hukum Kedokteran, Bandung, Alpa Beta, 2017.

\section{Jurnal}

Bunga Agustina, Kewenangan Pemerintah Dalam Perlindungan Hukum Pelayanan Kesehatan Tradisional Ditinjau Dari Undang-Undang Republik Indonesia No. 36 Tahun 2009 Tentang Kesehatan, Jurnal Wawasan Hukum, Vol. 32. No. 1 Februari 2015.

Cici Bahkti Purnamasari, Mora Claramita, Pembelajaran Profesionalisme Kedokteran Dalam Persepsi Instruktur Dan Mahasiswa, Jurnal Pendidikan Kedokteran Indonesia, Vol. 4. No. 1. Maret 2015.

Fherial Sri Isriyawati, Tanggungjawab Negara Dalam Pemberian Hak Atas Kesehatan Masyarakat Berdasarkan Undang-Undang Dasar Negara Republik Indonesia Tahun 1945, Jurnal Ilmu Hukum Legal Opinion, Edisi 2. Vol. 3 Tahun 2015.

Mustajab, Analisis Yuridis Hubungan Hukum Antara Dokter Dan Pasien Dalam Pelayanan Kesehatan, Jurnal Ilmu Hukum Legal opinion. No. 4. Vol. 1 Tahun 2013.

Marcel Seran, Anna Mariah Wahyu Setyowati, Kesalahan Profesional Dokter Dan Urgensi Peradilan Profesi, Jurna Hukum Pro Justicia. Vol. 24. No. 4/ 2006. 
Peraturan Perundang-undangan

Undang-Undang Dasar Negara Republik Indonesia Tahun 1945

Undang-Undang No. 29 Tahun 2004 Tentang Peraktik Keokteran

Hasil Wawancara

Hasil wawancara Bersama Sekretaris Ikatan Dokter Indonesia Wilayah Riau dr. Abdullah Qayyum.

Hasil Wawancara Penulis Dengan Dosen Hukum Kesehatan Universitas Islam Indonesia, dr. Suryono. 